\title{
Initative for Introducing Latest Milk Vending Equipments in Rural Areas
}

\author{
J. Kannan, D. Venkatrama Raju
}

\begin{abstract}
The business is predominantly founded on dairy cows, despite the fact that there is a little goat and sheep part to the business. Dairy producers and processors increase the value of the milk and give work in local territories. About $9 \%$ of the State's milk generation is expended as drinking milk; the parity is fabricated by dairy organizations into items, for example, ghee, milk powders and spread. Dairy producers and processors legitimately utilize about individuals and the suppliers of merchandise and enterprises to the business create extra work. The Domestic Market Support Scheme and the guideline of ranch entryway market milk costs stopped.
\end{abstract}

Keywords: Domestic Market system, Dairy Producers

\section{INTRODUCTION}

The dairy sector has developed through co-operatives in many parts of the State. During 1997-98, the State had 60 of 5.8 million litres per day[1]-[5]. In addition to these processing plants, 123 Government and 33 cooperatives milk chilling centre operate in the State. For the development of milk production. Milk Industry is concerned in all aspects with the production, processing and retailing of milk and milk products. An editorial mix of news, articles, interviews, business advice and technical reports provides a source of relevant information for anyone involved in milk production and dairy products processing and retailing.

\section{OBJECTIVES}

1. To study the comparative Rural marketing strategies of Aavin, Arokya and Cavins milk in chennai district

2. To analyze the level of Rural consumers satisfaction of Aavin, Arokya and Cavins milk.

\section{A. Scope}

1. The satisfaction of the Rural consumer regarding Aavin milk, Arokya milk and Cavins milk in the understood through the research.

2. By identifying the expectation and satisfaction level the organization may increase the sales volume.

Revised Manuscript Received on December 11, 2019

J. Kannan, Department of Science and Humanities, Bharath Institute of Higher Education and Research, Chennai , India. Email: sjkannan1986@gmail.com

D. Venkatrama Raju, Department of Science and Humanities, Bharath Institute of Higher Education and Research, Chennai, India. Email: prof.dvraju@gmail.com milk processing plants with an aggregate processing capacity

\section{RESEARCH METHODOLOGY}

\section{A. Statement of the Problem}

This study also helps to know how specific rural marketing factor such as price, value, quantity, package to produce about different people's tastes, desires, likes, choices, etc. The research would help gain market share awareness for each product, customer-influencing factors preferring a specific brand of milk, and problems they face when using those brands[6]-[10]..

\section{B. Sample Design}

For this work 100 respondents are selected, and data were collected using the questionnaire.

\section{Opinion Of the Respondents}

Table - 1 The Rank About Aavin, Cavins And Arokya Milk Of The Respondents

\begin{tabular}{|l|c|c|c|c|l|l|}
\hline \multirow{2}{*}{ AAVIN } & AAVIN & & \multicolumn{2}{|c|}{ CAVINS } & \multicolumn{2}{|c|}{ AROKYA } \\
\cline { 2 - 6 } & $\begin{array}{l}\text { Responde } \\
\text { nts }\end{array}$ & $\begin{array}{l}\text { Percenta } \\
\text { ge }\end{array}$ & $\begin{array}{l}\text { Responde } \\
\text { nts }\end{array}$ & $\begin{array}{l}\text { Percenta } \\
\text { ge }\end{array}$ & $\begin{array}{l}\text { Respond } \\
\text { ents }\end{array}$ & $\begin{array}{l}\text { Percenta } \\
\text { ge }\end{array}$ \\
\hline I Rank & 78 & 52 & 12 & 8 & 45 & 30 \\
\hline II Rank & 33 & 22 & 69 & 46 & 56 & 37 \\
\hline III Rank & 39 & 26 & 69 & 46 & 49 & 33 \\
\hline TOTAL & 150 & 100 & 150 & 100 & 150 & 100 \\
\hline $\begin{array}{l}\text { Over all } \\
\text { weighted } \\
\text { score }\end{array}$ & \multicolumn{2}{|c|}{339} & \multicolumn{2}{|c|}{243} & \multicolumn{2}{|c|}{296} \\
\hline Rank & 1 & & 3 & & \\
\hline
\end{tabular}

It is inferred that first rank for aavin milk with over all weighted score 339 , second rank for Arokya milk with weighted score 296 and last rank for Cavins milk with a lowest score of 243

\section{RESULTS AND DISCUSSION}

- It is analyzed that majority (42\%) of the respondents are age between 20-25 years.

- Most of the respondents are $58 \%$ in female in gender.

- It is found that majority (62\%) of the responds are belong to unmarried

- It is analyzed that majority (44\%) of the assenters are belongs to education in college level.

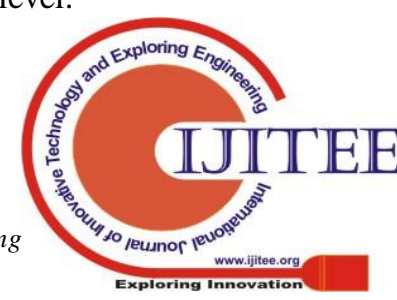




\section{Initative for Introducing Latest Milk Vending Equipments in Rural Areas}

- Majority (58\%) of the respondents are belongs to occupation in business[11]-[15].

- It is noted that greater part $(48 \%)$ of the assenters are income between rs 3001-rs 8000.

- Majority (36\%) of the respondents are belongs 3-5 members of family size.

- It is analyzed that majority (46\%) of the respondents are belongs arokya milk producd.

- It is found that majority $(52 \%)$ of the respondents are belongs 2-3 litters of milk per day producing.

- Majority (52\%) of the respondents are belongs aavin milk of brand.

- It is analyzed that majority (28\%) of the respondents are belongs quality of buying reason.

- It is concluded that Majority (48\%) of the respondents are belongs advertisement of know about the brand.

- It is found that majority $(64 \%)$ of the respondents are belongs quantity of influence buying for brand.

- It is analyzed that majority (48\%) of the respondents are belongs retails shop of purchase milk.

- It is noted that majority (70\%) of the respondents are quality satisfaction level of highly satisfied for Aavin milk.

- It is found that majority (42\%) of the respondents are quality satisfaction level of satisfied for cavins milk.

- It is found that majority (40\%) of the respondents are quality satisfaction level of highly dissatisfied for Arokya milk.

- It is found that majority (78\%) of the respondents are quantity satisfaction level of highly satisfied for Aavin milk.

- It is concluded that majority (40\%) of the respondents are quantity satisfaction level of satisfied for cavin milk.

- It is found that majority (42\%) of the respondents are quantity satisfaction level of highly dissatisfied for Arokya milk[16]-[20].

- It is found that majority (76\%) of the respondents are price satisfaction level of highly satisfied for Aavin milk.

- It is concluded that majority (38\%) of the respondents are price satisfaction level of satisfied for cavin milk.

- It is noted that majority (46\%) of the respondents are price satisfaction level of highly dissatisfied for Arokya milk.

- It is found that majority (74\%) of the respondents are package satisfaction level of highly satisfied for Aavin milk.

- It is found that majority (38\%) of the respondents are package satisfaction level of satisfied for cavin milk.

- It is concluded that majority (48\%) of the respondents are package satisfaction level of highly dissatisfied for Aavin milk.

- It is found that majority ( $72 \%)$ of the respondents are taste satisfaction level of highly satisfied for Aavin milk.

- It is found that majority ( $42 \%$ ) of the respondents are taste satisfaction level of satisfied for cavin milk.
- It is concluded that majority (46\%) of the respondents are taste satisfaction level of highly dissatisfied for Arokya milk. - It is found that majority (70\%) of the respondents are availability satisfaction level of highly satisfied for Aavin milk.

- It is concluded that majority (40\%) of the respondents are availability satisfaction level of satisfied for cavin milk.

- It is found that majority (44\%) of the respondents are availability satisfaction level of highly dissatisfied for Aroyka milk.

- It is found that majority $(80 \%)$ of the respondents are freshness satisfaction level of highly satisfied for Aavin milk.

- It is noted that majority (38\%) of the respondents are freshness satisfaction level of highly satisfied for cavin milk.

- It is found that majority (48\%) of the respondents are freshness satisfaction level of highly dissatisfied for Arokya milk[21]-[23].

- It is concluded that majority (74\%) of the respondents are image satisfaction level of highly satisfied for Aavin milk.

- It is found that majority (34\%) of the respondents are image satisfaction level of highly satisfied for cavin milk.

- It is concluded that majority (48\%) of the respondents are image satisfaction level of highly dissatisfied for Arokya milk.

- It is found that majority $(74 \%)$ of the respondents are image satisfaction level of highly satisfied for Aavin milk.

- It is concluded that the majority of respondents $(52 \%)$ belong to 1 Aavin milk rank.

- It is concluded that the correlation between age and favorite milk between customers is not important.

- It is concluded that there is no significant relationship between customers between age and preferred milk.

\section{SUGGESTIONS}

- The consumers feel that the price of the full cream milk should be reduced.

- Should give special discount for cardholders.

- The product feature should be clearly communicated through advertisement[24]-[25].

- The availability of Aavin, Arokya, cavin milk is good on only urban area but rural people are not enjoy those benefits, so Aavin, Arokya cavin milk is now develop their availability in both rural and urban areas.

\section{CONCLUSION}

In our day - to-day life certain products are very important to us. Milk is one of the products which occupy the major part in our life. We cannot imagine a life without these milk products. Everyone wants that the milk product should be Pure, Quality and Original. So the company should take care 
of the need and expectation of the consumers.

\section{REFERENCES}

1) Vasanthi, S. \& Rabiyathul Basariya, S. 2019, "Influence of value analysis and cross training in industry", International Journal of Engineering and Advanced Technology, vol. 8, no. 6, pp. 1810-1811.

2) Velvizhi, R., Sri Gowtham, S. \& Jeya Priya, D. 2019, "Examination of early feedbacks for effective product retailing on E-commerce websites", International Journal of Engineering and Advanced Technology, vol. 8, no. 6 Special Issue 2, pp. 703-706.

3) Anuradha, C., Pothumani, S. \& Kavitha, R. 2019, "A novel method towards E-commerce", International Journal of Engineering and Advanced Technology, vol. 8, no. 6 Special Issue 2, pp. 535-538.

4) Thomas, J. \& Rabiyathul Basariya, S. 2019, "A study on the issues of financial ratio analysis", Indian Journal of Public Health Research and Development, vol. 10, no. 3, pp. 1079-1081.

5) Ramachandran, S. \& Rabiyathul Basariya, S. 2019, "Online marketing study on customer satisfaction and relationship", Indian Journal of Public Health Research and Development, vol. 10, no. 3, pp. 1072-1078.

6) Priya, R., Vinothini, G. \& Cor Jesu, C.D. 2019, "The mentor-protégé relationship for professional growth", Journal of Advanced Research in Dynamical and Control Systems, vol. 11, no. 9 Special Issue, pp. 1110-1119.

7) Jannifer Rani, N., Bina Pani, S. \& Nimisha, N.S. 2019, "A study on money back polices available in LIC", Journal of Advanced Research in Dynamical and Control Systems, vol. 11, no. 9 Special Issue, pp. 833-839.

8) Saillaja, V., Jhansi Rani, K. \& Catherine, R. 2019, "Global marketing management planning and organization", Journal of Advanced Research in Dynamical and Control Systems, vol. 11, no. 9 Special Issue, pp. 489-493.

9) Saillaja, V., Jhansi Rani, K. \& Catherine, R. 2019, "The new phase of marketing information system", Journal of Advanced Research in Dynamical and Control Systems, vol. 11, no. 9 Special Issue, pp. 482-488.

10) Thoufiqulla \& Raju, D.V. 2019, "Perception of indian investor towards investment in mutual funds with special reference to mip funds", Journal of Advanced Research in Dynamical and Control Systems, vol. 11, no. 5, pp. 177-183.

11) Jasmine, K.R.M. \& Basariya, S.R. 2018, "A study on the customers benefits on mutual funds", International Journal of Civil Engineering and Technology, vol. 9, no. 4, pp. 45-48.

12) Vasanthi, S. \& Basariya, S.R. 2019, "Pros and cons of on the job training versus off the job training", International Journal of Scientific and Technology Research, vol. 8, no. 10, pp. 671-674.

13) Pavithra, J. \& Ganesan, M. 2016, "A study on awareness and impact of micro-financial schemes", International Journal of Applied Business and Economic Research, vol. 14, no. 8, pp. 5449-5460.

14) Pavithra, J., Dilli Babu, P. \& Ambuli, T.V. 2014, "A study on budgetary control at Maruti Service Masters, Chennai", International Journal of Applied Business and Economic Research, vol. 12, no. 2, pp. 151-161.

15) Gunaraja, T.M. \& Venkatrama Raju, D. 2018, "Determining factors of organisational climate with reference to leadership styles", International Journal of Mechanical Engineering and Technology, vol. 9, no. 9, pp. 1327-1332.

16) Gunaraja, T.M. \& Venkatrama Raju, D. 2018, "The role of job satisfaction and training of employees in determining organisational climate of a selected industry", International Journal of Civil Engineering and Technology, vol. 9, no. 8, pp. 1266-1269.

17) Aarathy, T.S. \& Raju, D.V. 2018, "Performance appraisal and its effects on employees with respect to it sector in Chennai city", International Journal of Civil Engineering and Technology, vol. 9, no. 6, pp. $1535-1538$.

18) Aarathy, T.S. \& Raju, D.V. 2018, "Employee perception towards performance appraisal system in IT sector", International Journal of Mechanical Engineering and Technology, vol. 9, no. 5, pp. 131-135.

19) Porselvi, W., Jublee, D. \& Sivanesan, G. 2018, "A study on factors influencing adoption of technology and innovation in banking industry, tamilnadu, India", International Journal of Mechanical Engineering and Technology, vol. 9, no. 5, pp. 789-800.

20) Akessa, G.M. and Dhufera, A.G., 2015. Factors That Influences Students Academic Performance: A Case of Rift Valley University, Jimma, Ethiopia. Journal of Education and Practice, 6(22), pp.55-63.

21) Miller, G. and Shih, C.C., 1999. A faculty assessment of the academic rigor of on-and off-campus courses in agriculture. Journal of Agricultural Education, 40, pp.57-65.

22) Tsinidou, M., Gerogiannis, V. and Fitsilis, P., 2010. Evaluation of the factors that determine quality in higher education: an empirical study. Quality Assurance in education, 18(3), pp.227-244.
23) Farooq, M.S., Chaudhry, A.H., Shafiq, M. and Berhanu, G., 2011. Factors affecting students' quality of academic performance: a case of secondary school level. Journal of quality and technology management, 7(2), pp.1-14.

24) Fitsilis, P., Gerogiannis, V. and Anthopoulos, L., 2014. Ontologies for software project management: a review. Journal of Software Engineering and Applications, 7(13), p.1096.

25) Adams, J.D. and Jaffe, A.B., 1996. Bounding the effects of R\&D: an investigation using matched establishment-firm data(No. w5544). National bureau of economic research.

\section{AUTHORS PROFILE}

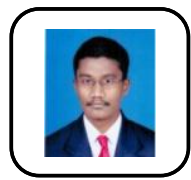

J. Kannan Associate Professor, Department of Science and Humanities, Bharath Institute of Higher Education and Research, Chennai, India.

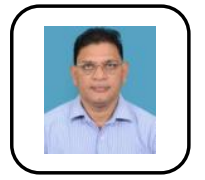

D. Venkatrama Raju Professor, Department of Science and Humanities, Bharath Institute of Higher Education and Research, Chennai, India. 